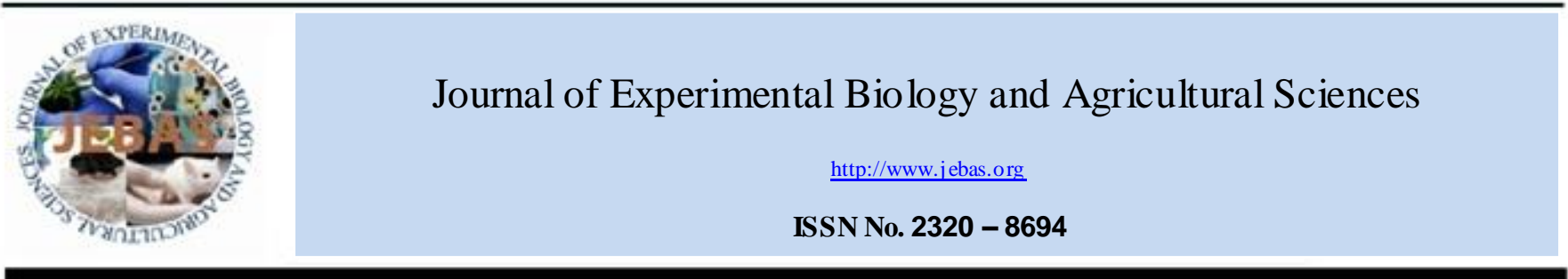

\title{
PHENOTYPIC STABILITY AND GGE BIPLOT ANALYSIS IN PIGEONPEA [Cajanus cajan (L.) Millsp.] GENOTYPES ACROSS THE ENVIRONMENTS
}

\author{
Nalin Pagi ${ }^{1 *}$, Darshan Dharajiya ${ }^{1}$, Y. Ravindrababu², Karen Pachchigar ${ }^{1}$, Nishit Soni ${ }^{1}$, \\ Laxmansinh Parmar ${ }^{3}$, Jasvantlal Patel ${ }^{4}$, Ravindrasinh Chauhan ${ }^{5}$, Manubhai Patel ${ }^{1}$
}

\footnotetext{
${ }^{1}$ Department of Genetics and Plant Breeding, C. P. College of Agri culture, S. D. Agricultural University, Sardark rushinag ar - 385506, Gujarat, Indi a.

${ }^{2}$ Pulses Research Station, S. D. Agricultural University, Sard arkrus hinagar - 385506, Gujarat, India.

${ }^{3}$ Department of Genetics and Plant Breeding, College of Agri culture, S.D. Agricultural Uni versity, Tharad - 385565, Guj arat, India.

${ }^{4}$ Wheat Research Station, S. D. Agricultural University, Vijapur - 382870, Gujarat, India.

${ }^{5}$ Department of Seed Technology, S. D. Agricultural University, Sardark rushinag ar - 385506, Gujarat, India.
}

Received - March 09, 2017; Revision - May 03, 2017; Accepted - June 20, 2017 Available

Avail able Online - June 30, 2017

http://dx.doi.org/10.18006/2017.5(3).359.367

KEYWORDS
G $\times$ E interaction
Pearson correlation
Phenotypic stability
GGE Biplot and Cajanus
cajan (L.) Millsp

cajan (L.) Millsp

\begin{abstract}
Phenotypic stability was carried out by using Eberhart \& Russell model, as well as recent GGE biplot approach for identification of the foremost genotypes across the different environments in pigeonpea [Cajanus cajan (L.) Millsp.] genotypes. Further, Pearson correlation was carried out to correlate the different yield contributing attributes with seed yield. Fifty six pigeonpea genotypes comprising fourteen parents, forty hybrids and two standard checks were evaluated at four environments during kharif season of 2013 and 2014, to study genotype $x$ environment interaction for yield and related traits. A significant difference was obtained for yield and yield contributing characters among genotypes in individual as well as pooled environments except for pod length, 100 seed weight and seed protein content (\%). For traits like days to maturity, plant height, pods per plant, pod clusters per plant, seeds per pod, 100 seed weight and seed yield per plant Genotypes $\times$ Environments (linear) values were significant when tested against pooled deviation. Some hybrids such as GT $610 \mathrm{~A} \times$ GTR 84 $(119.79 \mathrm{~g})$, GT $603 \mathrm{~A} \times$ GTR 81 (119.41 g), GT $610 \mathrm{~A} \times$ GT R $82(119.20 \mathrm{~g})$, GT $607 \mathrm{~A} \times$ GTR $82(116.07 \mathrm{~g})$, GT $601 \mathrm{~A} \times$ GTR $82(113.03 \mathrm{~g})$ and GT $604 \mathrm{~A} \times$ GTR $81(110.92 \mathrm{~g})$ depicted significant stability for the yield and yield components by Eberhart \& Russell model. Similar results were observed by GGE biplot analysis for three hybrids viz., GT $610 \mathrm{~A} \times$ GTR 84 (119.79 g), GT $603 \mathrm{~A} \times$ GTR 81(119.41 g) and GT $610 \mathrm{~A} \times$ GTR 82 $(119.20 \mathrm{~g})$ which depicted significant stability for the yield and its components and could be promising for cultivation across different environments in Western India.
\end{abstract}

* Correspon ding author

E-mail: nalinpagi2007@gmail.com (Nalin Pagi)

Peer review under responsibility of Journal of Experiment al Biology and Agricultural Sciences.

Production and Hosting by Horizon Publisher Indi a [HPI] (http://ww w.hori zon publish erindi a.in/).

All rights reserved.
All the article published by Journal of Experimental Biology and Agricultural Sciences is licensed under a Creative Commons Attribution-NonCommercial 4.0 International License Based on a work at www.jebas.org.

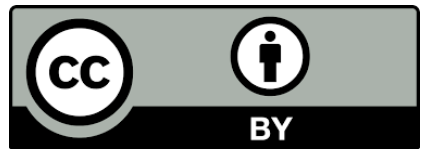




\section{Introduction}

Pulses are climate smart and have been a nutritious part of the international diet for centuries. Nevertheless "slow runner" (Borlaug, 1972), pulses steadily rise in popularity among people and captured international attention due to their multi facet, nutrients and healthy diet appeal. The 2016 year has been declared as the "International Year of Pulses"/IYP-2016, on a global scale which would enhance productivity and awareness on pulses (Brick \& Fisher, 2016). One of the fascinating legume crop pigeonpea [Cajanus cajan (L.) Millspaugh] belong to diploid genome $(2 \mathrm{n}=$ $2 \mathrm{x}=22$ ) (Reddy et al., 1980) and have $\sim 833.0 \mathrm{Mb}$ of genome size (Varshney et al., 2012; Singh et al., 2012). It is the best versatile food legume, span over a wide area of the world with diversified uses and also benchmark with "sustainable agriculture" with enormous existing wild diversity, India is considered to be the "hot spot" and center of origin for pigeonpea (Van der Maesen, 1990). It is well known as finest nitrogen fixer and nutrient re-cycler (Graham \& Vance, 2003; Srivastava et al., 2012). In India, the crop was grown under 3.90 million hectares with 3.17 million tonnes production having low productivity of $813 \mathrm{~kg} / \mathrm{ha}$ during 2013-14 (Anonymous, 2017).

The lower productivity of the crop was the big concern that directly or indirectly affects the national food security hence reasons for lower productivity of the crop was the issue to be debated in numbers of forward thinking sessions in India. Some studies revealed that the yield plateau could be broken by identifying new and stable sources of male sterility or resistance for biotic-abiotic stresses from wild germplasm and also by adopting molecular tools for creating variability for use in future (Pagi et al., 2016).

To address this long standing yield stagnation in pigeonpea, Cytoplasmic Male Sterile (CMS) or Cytoplasmic Genetic Male Sterile (CGMS) based hybrids were used in breeding programme at the State Agricultural Universities (SAUs) having $\mathrm{A}_{2}$ cytoplasms from C. scarabaeoides (Tikka et al., 1997; Saxena \& Kumar, 2003) and at the International Crops Research Institute for the Semi-Arid Tropics (ICRISAT) hybrids having $\mathrm{A}_{4}$ type of cytoplasm from Cajanus cajanifolius (Saxena et al., 2005). Hence, the cytoplasmic genetic male sterility technology has flagged a way for heterosis breeding and set a stage for breaking the yield plateau.

For heterogeneous varieties in terms of their domain of time and space, assessing their Genotype $\mathrm{x}$ Environment interaction is indispensable and worthy for predicting their stability across environment. The success of variety of any crop depends upon its stable performance over varied environments (Wanjari et al., 1988). Hence, identifying the stable genotypes across the environments for yield and its attributing traits is the prime requisite for any breeding programmes. The GGE (Genotype and GenotypexEnvironment interaction) biplot methodology of analyzing Multi-Environment Trial (MET) data has emerged as a powerful tool for $\mathrm{G} \times \mathrm{E}$ analysis with smart and immaculate visual outputs for plant breeders, quantitative geneticist and agronomists (Yan et al.,2000; Yan \& Kang, 2003; Yan \& Tinker, 2006). This approach puts $\mathrm{G}$ and GE interaction together called GGE (Yan et al., 2000), on a graphic biplot imagining tool based on methodology endorsed by Gabriel (1971). Hence, the present investigation was planned and executed to understand the $\mathrm{G} \times \mathrm{E}$ interaction of $\mathrm{A}_{2}$ cytoplasm based pigeonpea hybrids and varieties over the geographical locations for yield and its attributes conferring their stability by using Eberhart \& Russell model as well as GGE biplot analysis.

\section{Materials and Me thods}

The field trials were conducted during kharif 2012 to 2014.During kharif 2012, the genotypes were developed by crossing ten CMS lines viz., GT 601 A, GT 602 A, GT 603 A, GT 604 A, GT 605 A, GT 606 A, GT 607 A, GT 608 A, GT 609 A and GT 610 A containing $\mathrm{A}_{2}$ cytoplasm (Tikka et al., 1997; Saxena \& Kumar, 2003 ) with four different fertility restorers i.e., GTR 81 , GTR 82 , GTR 83 and GTR 84 . The crosses were attempted in line $\times$ tester mating design. The resultant $\mathrm{F}_{1} \mathrm{~s}$ along with their parents and two standard checks (GT 101 and GTH-1) were evaluated at two different location i.e., Pulses Research Station ( $24^{\circ} 12^{\prime}$ N, $72^{\circ} 12^{\prime}$ E and $154.5 \mathrm{~m})$, Sardarkrushinagar Dantiwada Agricultural University (SDAU), Sardarkrushinagar and Main Maize Research Station (23 $76^{\prime} \mathrm{N}, 73^{\circ} 24^{\prime} \mathrm{E}$ and $204 \mathrm{~m}$ ), SDAU, Bhiloda during the kharif seasons of the year 2013 and 2014, using a Randomized Block Design (RBD) with three replications.The observations for eleven characters viz, days to flowering (DF), days to maturity (DM), plant height $(\mathrm{PH})$ in $\mathrm{cm}$, number of branches per plant (NBP), pod clusters per plant (PCP), pods per plant (PP), seeds per pod $(\mathrm{SP})$, pod length $(\mathrm{PL})(\mathrm{cm}), 100$ seed weight $(\mathrm{SW})$ in $\mathrm{g}$, seed yield per plant(SYP) in $\mathrm{g}$ and protein content (PC) (\%) were recorded after random selection of five plants from the each plots. All the cultural practices were adopted to raise a normal healthy crop (Mula et al., 2010).

Statistical analysis was carried out using INDOST AT software. Analysis of variance was partitioned into variation due to genotypes, environments and genotype by environment interaction. The stability analysis was done as per suggested by Eberhart \& Russell model (1966).The stable genotypes were further studied to estimate the main and genotype-environment interaction effect for seed yield, using GGE ( $\mathrm{G}$ = genotype effect and GE = genotypeby-environment) biplot approach proposed by Yan (1999) and Yan et al., (2000).The GGE biplot analysis was done using PBTools software version 1.4 (PBTools, 2014).The asset of the association 
between yield and its components were verified using Pearson correlation analysis computed by XLST AT version 2015.6.03.

\section{Results and Discussion}

The genotypes which are phenotypically stable are of immense important for viable production of crop plants. According to Eberhart \& Russell (1966) model of stability analysis, three kinds of linear responses of regression coefficient (bi) have been considered and interpreted as $b i=1$, average stability and widely adaptable to different environments; bi $>1$, below average stability, increasing sensitivity to environmental changes and well adapted to favorable environment and bi<1, above average stability, greater tolerance to environmental changes; thereby genotypes would have specific adaptability to poor yielding environment.

The current study was conducted to have the information about the performance of newly developed cross combinations and controls across diverse environments. All the fifty six genotypes were significantly differed from each other signifying presence of variation among them to carry out study (Table 1 ). Therefore, the mean performance of hybrids for phenotypic stability and $\mathrm{G} \times \mathrm{E}$ interaction was deduced. The genotypes $\times$ environment interaction was found significant for days to maturity, plant height, pod clusters per plant, pods per plant, seeds per pod, 100-seed weight and seed yield per plant which indicates that genotypes interacted differently with environmental variations for above characters. Those characters which observed significant for $\mathrm{G} \times \mathrm{E}$ interaction were also reported significant for $\mathrm{G} \times \mathrm{E}$ (linear) and possessed higher value than the non linear components i.e. pooled deviation. Phad et al (2005) also found significant Gx E interaction for yield and its related traits of pigeonpea. This reflected greater importance of linear portion in building up total $\mathrm{G} \times \mathrm{E}$ interactions and the possibility of prediction across the environments for these characters.

The analysis of variance for stability analysis revealed that genotype $\times$ environments interaction was significant (Table 1 ). The linear components were found to be more significant for both linear and pooled deviation of $\mathrm{G} \times \mathrm{E}$ study. The significance of linear component of $\mathrm{G} \times \mathrm{E}$ interaction sugge sted that the genotypes responded in linear fashion to environments and performance could be predicted.

Eighteen hybrids had higher mean than average mean $(94.18 \mathrm{~g})$ among these hybrids four and three hybrids were exhibiting significant $b_{i}$ and $S^{2} d_{i}$, which indicating more contribution from linear components of $\mathrm{G} \times \mathrm{E}$ interactions (Table 2). The six stable hybrids over environments were GT $610 \mathrm{~A} \times$ GT R 84 (119.79 g), GT $603 \mathrm{~A} \times$ GTR $81(119.41 \mathrm{~g})$, GT $610 \mathrm{~A} \times$ GTR $82(119.20 \mathrm{~g})$, GT $607 \mathrm{~A} \times$ GTR $82(116.07 \mathrm{~g})$, GT $601 \mathrm{~A} \times$ GTR $82(113.03 \mathrm{~g})$ and GT $604 \mathrm{~A} \times$ GTR 81 (110.92 $\mathrm{g})$ had higher mean than average mean, non-significant regression unity and least deviation from regression revealed that stable hybrids for varied environments for seed yield per plant (higher mean $>$ cross mean, $b_{i}=1 \mathrm{NS}, S^{2} d_{i}=0$ NS). Hybrids GT $609 \mathrm{~A} \times$ GTR 83 (110.56 g) and GT $606 \mathrm{~A} \times$ GTR 81 (104.63 g) had higher mean than average mean, significant regression above the unity and least deviation from regression revealed that stable hybrids for favourable environments for seed yield per plant (higher mean > cross mean, $b_{i}>1$ significant, $S^{2} d_{i}=0 N S$ ).

The mean yield of each genotype depends on the particular set of environmental conditions. It is, therefore, suggested that in order to identify stable genotype, actual testing over a wide range of environments. Hence, while selection, more emphasis should be

Table 1 Analysis of variance (mean squares) for phenotypic stability pertaining to various characters in pigeonpea

\begin{tabular}{|c|c|c|c|c|c|c|c|c|c|c|c|c|}
\hline \multirow[b]{2}{*}{$\begin{array}{l}\text { Source of } \\
\text { variation }\end{array}$} & \multirow[b]{2}{*}{ d.f. } & \multicolumn{11}{|c|}{ Characters } \\
\hline & & $\begin{array}{l}\text { Days to } \\
\text { flowering }\end{array}$ & $\begin{array}{l}\text { Days to } \\
\text { maturity }\end{array}$ & $\begin{array}{c}\text { Plant } \\
\text { height } \\
(\mathrm{cm})\end{array}$ & $\begin{array}{c}\text { Number } \\
\text { of } \\
\text { branches } \\
\text { per plant }\end{array}$ & $\begin{array}{c}\text { Pod } \\
\text { clusters } \\
\text { per plant }\end{array}$ & $\begin{array}{l}\text { Pods per } \\
\text { plant }\end{array}$ & $\begin{array}{l}\text { Seeds } \\
\text { per } \\
\text { pod }\end{array}$ & \begin{tabular}{|c|} 
Pod \\
length \\
$(\mathrm{cm})$
\end{tabular} & $\begin{array}{c}100- \\
\text { seed } \\
\text { weight } \\
(\mathrm{g})\end{array}$ & $\begin{array}{l}\text { Seed yield } \\
\text { per } \\
\text { plant (g) }\end{array}$ & $\begin{array}{c}\text { Protein } \\
\text { content } \\
(\%)\end{array}$ \\
\hline $\begin{array}{l}\text { Genotypes } \\
\text { (G) }\end{array}$ & 55 & $288.15^{* *}$ & $119.43^{* *}$ & $12852.35^{* * *}$ & $1.32 * *$ & $269.52^{* *}$ & $7268.51 * *$ & $0.14 * *$ & 0.20 & $1.95 * *$ & $1355.61 * *$ & 36.85 *** \\
\hline $\begin{array}{l}\text { Environments } \\
\text { (E) }\end{array}$ & 3 & $155.67 * *$ & $132.27 * *$ & $806.27 * *$ & $3.64 * *$ & $2267.72 * *$ & $1867.17 * *$ & $0.48 * *$ & 0.27 & 0.01 & $194.44 * *$ & 2.22 \\
\hline $\mathrm{G} \times \mathrm{E}$ & 165 & 2.59 & $9.46^{*}$ & $24.53 * *$ & 0.15 & $26.81 * *$ & $352.52 * *$ & $0.07 * *$ & 0.17 & $0.08 * *$ & $25.62 * *$ & 4.42 \\
\hline \begin{tabular}{|c|}
$\begin{array}{c}\text { Environments } \\
\text { (linear) }\end{array}$ \\
\end{tabular} & 1 & $467.00 * *$ & $396.82^{* *}$ & $2418.80 * *$ & $10.91 * *$ & $6803.15^{* *}$ & $5601.51 * *$ & $1.43 * *$ & $0.81 *$ & 0.02 & $583.33^{* *}$ & 6.65 \\
\hline $\mathrm{G} \times \mathrm{E}$ (linear) & 55 & $3.70 * *$ & $15.61^{* *}$ & $62.74 * *$ & 0.14 & $72.96^{* *}$ & $382.49 * *$ & $0.12 * *$ & 0.15 & $0.16 * *$ & $26.58 * *$ & 1.54 \\
\hline $\begin{array}{c}\text { Pooled } \\
\text { deviation }\end{array}$ & 112 & 1.99 & 6.27 & 5.33 & 0.15 & 3.67 & $331.51 * *$ & 0.04 & $0.18^{* *}$ & $0.04 * *$ & $22.74 * *$ & $5.76^{* * *}$ \\
\hline Pooled error & 440 & 6.15 & 9.21 & 80.83 & 0.14 & 13.04 & 128.84 & 0.03 & 0.06 & 0.06 & 27.36 & 0.32 \\
\hline
\end{tabular}

*, ** Significant at 5 and 1 per cent probability levels, respectively. 
Table 2 Stability analysis of hybrids for average, favorable and poor environments

\begin{tabular}{|c|c|c|c|c|c|c|}
\hline S. No. & En vironments & Hybrids & $\begin{array}{c}\text { Seed yield } \\
\text { per plant }(g)\end{array}$ & $\mathbf{B i}$ & $S^{2} \mathrm{di}$ & $\begin{array}{l}\text { Stability for component } \\
\text { characters }\end{array}$ \\
\hline \multirow{6}{*}{1.} & \multirow{6}{*}{ Average Env. } & GT $610 \mathrm{~A} \times$ GTR 84 & 119.79 & 2.80 & 24.35 & $\mathrm{DM}, \mathrm{PP}, \mathrm{SP}, \mathrm{SW}$ \\
\hline & & GT603 A × GTR 81 & 119.41 & 2.71 & 65.59 & DM, PCP, PP, SP, SW \\
\hline & & GT610 A $\times$ GTR 82 & 119.20 & 3.83 & 30.54 & $\mathrm{DM}, \mathrm{PP}, \mathrm{SP}, \mathrm{SW}$ \\
\hline & & GT607 A × GTR 82 & 116.07 & 4.28 & 31.67 & $\mathrm{DM}, \mathrm{PCP}, \mathrm{PP}, \mathrm{SP}, \mathrm{SW}$ \\
\hline & & GT $601 \mathrm{~A} \times$ GTR 82 & 113.03 & 4.80 & -8.66 & $\mathrm{DM}, \mathrm{NBP}, \mathrm{SP}$ \\
\hline & & GT604 A × GTR 81 & 110.92 & -0.34 & 18.98 & DM, PCP, PP, SP, SW \\
\hline \multirow[b]{2}{*}{2.} & \multirow{2}{*}{ Fa vorable Env. } & GT $609 \mathrm{~A} \times$ GTR 83 & 110.56 & $3.53^{*}$ & -31.34 & $\mathrm{PH}, \mathrm{SP}$ \\
\hline & & GT $606 \mathrm{~A} \times$ GTR 81 & 104.63 & $3.29 *$ & -33.36 & - \\
\hline 3. & Poor Env. & - & - & - & - & \\
\hline
\end{tabular}

Table 3 Pearson correlation betweene different yield and yield contributing traits at four locations

\begin{tabular}{|c|c|c|c|c|c|c|c|c|c|c|c|}
\hline Variables & Environments & DF & DM & PH & NBP & PCP & PP & SPP & PL & SW & SYP \\
\hline \multirow{4}{*}{ DF } & Sardarkrushinagar 2013 & 1 & $0.467 * *$ & $0.372 * *$ & -0.207 & 0.151 & $0.395 * *$ & -0.057 & -0.001 & -0.17 & 0.286 \\
\hline & $\overline{\text { Bhiloda } 2013}$ & 1 & $0.517 * *$ & $0.445 * *$ & 0.080 & 0.204 & $0.455^{* * *}$ & -0.192 & -0.095 & -0.149 & 0.268 \\
\hline & Sardarkrushinagar 2014 & 1 & $0.611^{* * *}$ & $0.430 * *$ & -0.021 & 0.118 & $0.386^{* * *}$ & 0.033 & 0.176 & -0.138 & 0.267 \\
\hline & Bhiloda 2014 & 1 & 0.443 ** & 0.407 ** & 0.136 & 0.228 & 0.472 ** & 0.020 & -0.134 & -0.107 & 0.288 \\
\hline \multirow{4}{*}{ DM } & Sardarkrushinagar 2013 & & 1 & $0.345^{* * *}$ & 0.04 & 0.253 & 0.359 ** & -0.044 & -0.029 & 0.085 & $0.381^{* * *}$ \\
\hline & $\overline{\text { Bhiloda } 2013}$ & & 1 & $0.364 * *$ & 0.290 & $0.395 * *$ & 0.442 *** & -0.202 & -0.037 & 0.058 & $0.422 * *$ \\
\hline & Sardarkrushinagar 2014 & & 1 & 0.301 & 0.128 & 0.286 & 0.379 *** & 0.173 & -0.087 & 0.175 & 0.359 \\
\hline & Bhiloda 2014 & & 1 & 0.107 & 0.131 & 0.182 & 0.254 & 0.113 & 0.074 & 0.017 & 0.253 \\
\hline \multirow{4}{*}{ PH } & Sardarkrushinagar 2013 & & & 1 & -0.129 & $0.384 * *$ & $0.747^{* * *}$ & -0.101 & -0.043 & 0.117 & $0.424^{* * *}$ \\
\hline & Bhiloda 2013 & & & 1 & 0.014 & $0.481 * *$ & $0.744 * *$ & -0.292 & -0.016 & 0.038 & $0.395 * *$ \\
\hline & Sardarkrushinagar 2014 & & & 1 & -0.040 & 0.202 & 0.828 ** & 0.044 & 0.105 & -0.063 & $0.496 * * *$ \\
\hline & $\overline{\text { Bhiloda } 2014}$ & & & 1 & -0.024 & $0.416 * *$ & $0.707^{* *}$ & 0.100 & -0.243 & 0.052 & $0.448^{* * *}$ \\
\hline \multirow{4}{*}{ NBP } & Sardarkrushinagar 2013 & & & & 1 & -0.067 & -0.1 & -0.104 & -0.083 & 0.256 & 0.075 \\
\hline & $\overline{\text { Bhiloda } 2013}$ & & & & $\mathbf{1}$ & 0.128 & 0.224 & -0.068 & 0.201 & 0.331 & 0.250 \\
\hline & Sardarkrushinagar 2014 & & & & 1 & 0.203 & 0.015 & 0.058 & 0.037 & $0.479 * *$ & 0.075 \\
\hline & $\overline{\text { Bhiloda } 2014}$ & & & & 1 & 0.121 & 0.074 & -0.099 & 0.042 & 0.178 & 0.273 \\
\hline \multirow{4}{*}{ PCP } & Sardarkrushinagar 2013 & & & & & 1 & 0.258 & -0.001 & 0.164 & 0.252 & 0.334 \\
\hline & Bhiloda 2013 & & & & & 1 & $0.389 * *$ & -0.127 & 0.081 & 0.179 & $0.459 * *$ \\
\hline & Sardarkrushinagar 2014 & & & & & 1 & 0.112 & 0.024 & -0.027 & 0.283 & -0.031 \\
\hline & $\overline{\text { Bhiloda } 2014}$ & & & & & 1 & 0.410 *** & 0.150 & -0.062 & 0.140 & $0.371^{* * *}$ \\
\hline \multirow{4}{*}{$\mathbf{P P}$} & Sardarkrushinagar 2013 & & & & & & $\mathbf{1}$ & -0.175 & -0.093 & 0.077 & $0.640^{* * * *}$ \\
\hline & Bhiloda 2013 & & & & & & 1 & -0.160 & -0.070 & 0.124 & $0.724 * * *$ \\
\hline & Sardarkrushinagar 2014 & & & & & & 1 & 0.022 & 0.172 & 0.048 & $0.670^{* * *}$ \\
\hline & Bhiloda 2014 & & & & & & 1 & -0.087 & -0.213 & 0.064 & $0.678 * *$ \\
\hline \multirow{4}{*}{ SPP } & Sardarkrushinagar 2013 & & & & & & & 1 & 0.256 & 0.074 & 0.12 \\
\hline & Bhiloda 2013 & & & & & & & 1 & 0.070 & 0.015 & 0.174 \\
\hline & Sardarkrushinagar 2014 & & & & & & & 1 & -0.103 & 0.090 & 0.290 \\
\hline & $\overline{\text { Bhiloda } 2014}$ & & & & & & & 1 & -0.208 & -0.059 & 0.032 \\
\hline \multirow{4}{*}{ PL } & Sardarkrushinagar 2013 & & & & & & & & $\mathbf{1}$ & 0.103 & 0.133 \\
\hline & Bhiloda 2013 & & & & & & & & $\mathbf{1}$ & 0.242 & -0.029 \\
\hline & Sardarkrushinagar 2014 & & & & & & & & 1 & -0.010 & 0.081 \\
\hline & Bhiloda 2014 & & & & & & & & 1 & -0.047 & -0.195 \\
\hline \multirow{4}{*}{ SW } & Sardarkrushinagar 2013 & & & & & & & & & 1 & $0.347^{* * *}$ \\
\hline & Bhiloda 2013 & & & & & & & & & $\mathbf{1}$ & $\overline{0.246}$ \\
\hline & Sardarkrushinagar 2014 & & & & & & & & & 1 & 0.252 \\
\hline & Bhiloda 2014 & & & & & & & & & 1 & 0.239 \\
\hline \multirow{4}{*}{ SYP } & Sardarkrushinagar 2013 & & & & & & & & & & 1 \\
\hline & Bhiloda 2013 & & & & & & & & & & 1 \\
\hline & Sardarkrushinagar 2014 & & & & & & & & & & 1 \\
\hline & Bhiloda 2014 & & & & & & & & & & 1 \\
\hline
\end{tabular}

Values in bold with ** marks are different from 0 with a significance level alpha of 0.01 and significant at $\mathrm{p}<0.0001$; DF $=$ Days to flowering, $\mathrm{PP}=$ Pods per plant, $\mathrm{DM}=$ Days to mat urity, $\mathrm{SP}=$ Seeds per pod, $\mathrm{PH}=$ Plant height $(\mathrm{cm}), \mathrm{PL}=$ Pod length $(\mathrm{cm}), \mathrm{NBP}=\mathrm{Number}$ of branches per plant, $\mathrm{SW}=100$-seed weight $(\mathrm{g}), \mathrm{PCP}=$ Pod clusters per plant, $\mathrm{SYP}=$ Seed yield per plant $(\mathrm{g})$. 
paid to the phenotypic stability of traits which were directly related to seed yield per plant to achieve maximum stability for the end product i.e., seed yield in pigeonpea.

Phenotypic stability of various component traits deciphering their seed yield stability was also reported by various workers viz, Vanniarajan et al.,2000; Patel, 2004; Vanniarajan et al., 2007; Patel et al., 2009; Sreelakshmi et al., 2010; Sawargaonkar et al., 2011; Pawar et al., 2013 and Chand et al., 2014.

\subsection{Correlation among the traits}

The correlation coefficients were estimated among all the pairs of variables (Table 3). The traits, days to maturity, plant height and pods per plant had a positive and significant association with days to flowering for Sardarkrushinagar and Bhiloda in kharif 2013 and 2014.The plant height was a significant and exhibited positive correlation with days to mat urity at Sardarkrushinagar and Bhiloda during kharif 2013. The significant and positive correlation was exhibited by pod clusters per plant with days to maturity (at Bhiloda, during kharif 2013) and plant height among locations. The number of pods per plant showed significant and positive association with days to flowering and plant height at all the environments, while it was significantly correlated in desired direction with pod clusters per plant at Bhiloda during kharif 2013 and kharif 2014. Hundred seed weight found significant and positively correlated with the number of branches per plant at Sardarkrushinagar during kharif 2013 and kharif 2014 while, plant height and pods per plant depicted positive correlation with seed yield across the environments. Seed yield also exhibited a significant and positive relationship with days to maturity during kharif 2013 at both the locations and pod clusters per plant during kharif 2013 and 2014 at Bhiloda. It indicated that these characters may be used in selection indices for amelioration of seed yield in pigeonpea for high yield. Similar findings were also reported by Sa wargaonkar et al. (2011) in pigeonpea.

\subsection{GGE Biplot analysis for parents and hybrids}

Asserting phenotypic stability of genotypes over MET is prerequisite for checking variety performance and for such objective in past research has been focused on mean performance and further modified it to incorporating with the interaction component as AMMI (Additive Main Effects and Multiplicative Environments). From, long with introduction of AMMI (Williams, 1952) and GGE biplot (Yan,1999; Yan et al., 2000), it has been always remain contrasting to choice one for better analysis.

Nevertheless, various modifications of the AMMI model were carried out; GGE biplots are thought to be a lucrative where biplot deliberates the relative magnitude of the $\mathrm{G}$, environment main effect, and IPC1. GGE biplot explains an intercession proportion of the sum of squares of both genotypes + genotypes by environments $(\mathrm{G}+\mathrm{GE})$, compared AMMI1 and AMMI2 megaenvironment graphs. To more details, GGE model emphasizes the fact that the so-called G not only has a genotypic basis, but also is dependent on the environmental conditions so $\mathrm{G}$ is influenced by GEI. Therefore, viewing G in terms of GEI has one potential advantage: an examination of PC1 scores not only identifies genotypes with better overall performance but also suggests environmental conditions that facilitate identification of these genotypes hence; it is believed that GGE biplots are more accurate than AMMI1 and more pragmatic than AMMI2 mega-environment (Yan et al., 2007). Hence, if purpose is to find which cultivar won in which environments, AMMI biplot could be misleading and GGE biplot could be more effective and practical as it displays the relative magnitude of the G, environment main effect and IPC1.

\subsection{What-won-where bi plot for vertex genotype}

In polygon "What-won-where" biplot genotype positioned as vertex showing longest detachment from biplot origin was considered to be most $\mathrm{G} \times \mathrm{E}$ interactive with stability.From our analysis biplot generated based on standard singular value decomposition model of untransformed mean seed yield data exhibited $98.6 \%$ (PC $1=95.9 \%, \mathrm{PC} 2=2.7 \%$ ) of total GGE variation, that strongly explained environment centered data and power of model to ascertain the stability of genotype across environment.

In the present study, the genotypes viz, $\mathrm{G}_{54}(119.79 \mathrm{~g}), \mathrm{G}_{23}(119.41$ $\mathrm{g}), \mathrm{G}_{52}(119.20 \mathrm{~g}), \mathrm{G}_{37}(113.37 \mathrm{~g})$ and $\mathrm{G}_{40}(116.07 \mathrm{~g})$ were the vertex genotype which had a higher seed yield (Figure 1). The three environments viz., $\mathrm{E}_{1}, \mathrm{E}_{3}$ and $\mathrm{E}_{4}$ were placed in the same plane on the graph, suggesting no significant difference among them. The individual environment, $\mathrm{E}_{2}$ was positioned in separate plane. For environment $\mathrm{E}_{2}, \mathrm{G}_{48}(107.58 \mathrm{~g})$ was the only vertex genotype. No single environment and the genotypes $\mathrm{G}_{11}, \mathrm{G}_{12}, \mathrm{G}_{13}$, $\mathrm{G}_{14}$ and $\mathrm{G}_{39}$ were placed in a same sector of the graph specifying that the said genotypes were not suitable for cultivation in these studied environments.

"Ideal genotypes" exhibits stable performance over wide range of environment with higher yield (Yan \& Kang, 2003). Among all the genotype, as per "ideal" view as shown in figure $2, \mathrm{G}_{54}(119.79 \mathrm{~g})$ found to be nearest to the "ideal genotype" followed by $\mathrm{G}_{52}$ (119.20 g) and $\mathrm{G}_{40}(116.07 \mathrm{~g})$.

\subsection{Ave rage yield and stability of genotypes based biplot}

Deciphering average mean performance with their phenotypic stability, a ranking or performing is achieved by drawing performance line (i.e. AEC) over GGE biplot. Here based on mean performance, ideal genotype is shown with an open blue the circle with arrows indicating absolute stable genotype, located on AEC abscissa as shown in figure 2. Hence, genotypes closer to circle are consistently stable while cultivar (genotype) farthest from point 


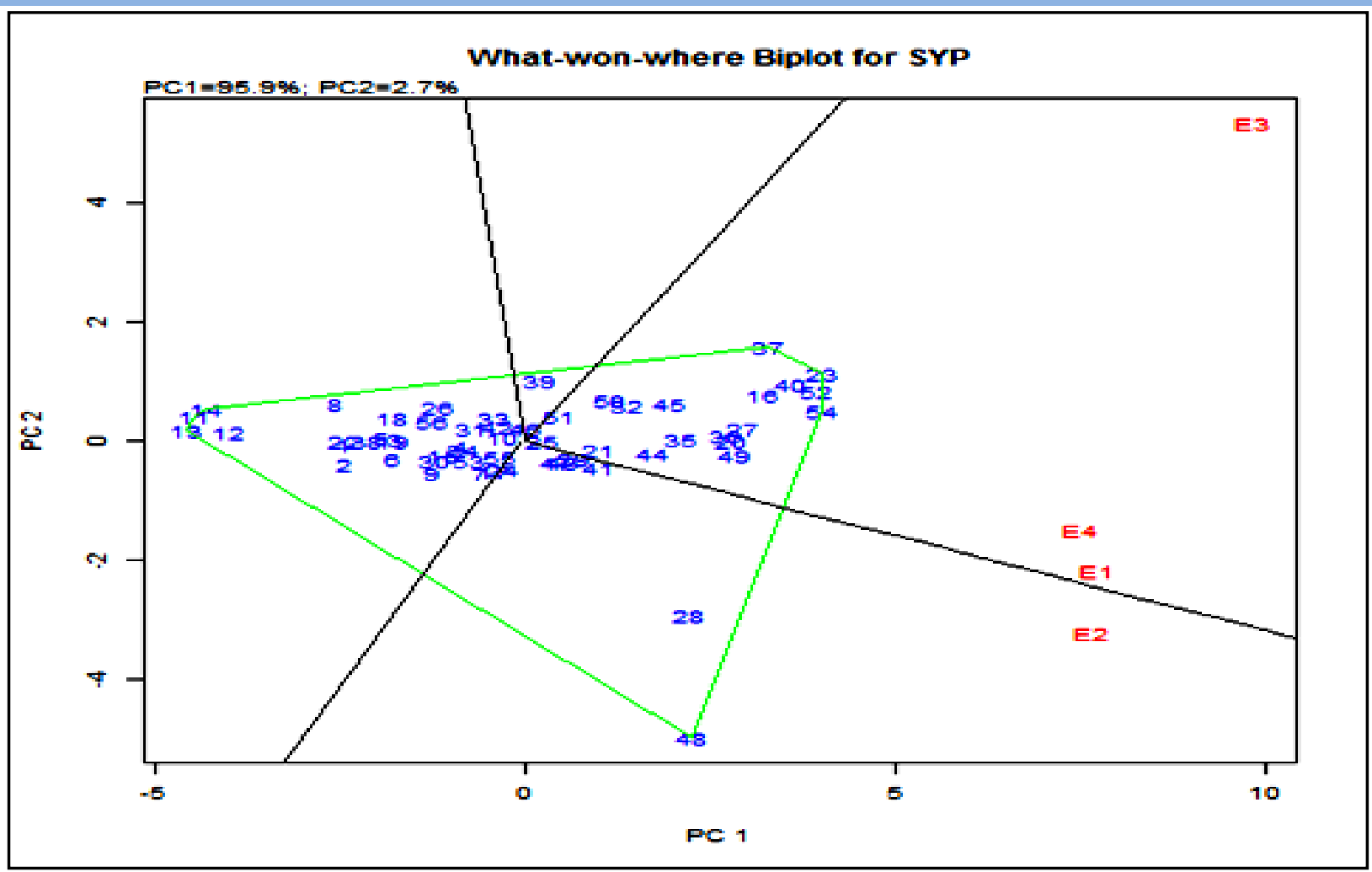

Figure 1 Polygon view of the GGE biplot, showing which genotype yielded best in which environments

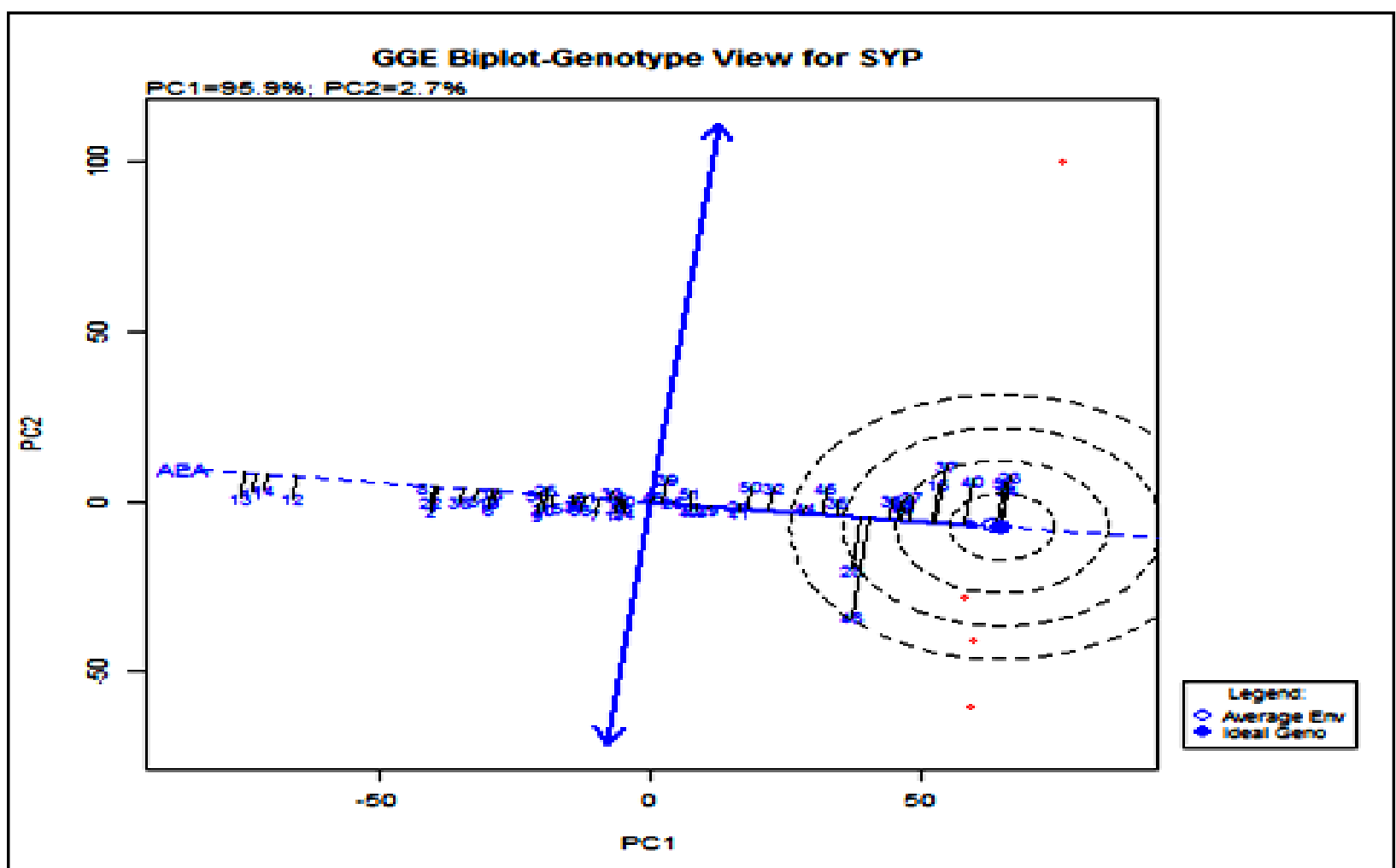

Figure 2 Comparison of genotypes with the ideal genotype showing the environmental axis (AEA) the GGE biplot. Environments and genotypes are denoted by 'E' and 'numeric value', respectively.

Journal of Experimental Biology and Agriculture Science http://www.jebas.org 


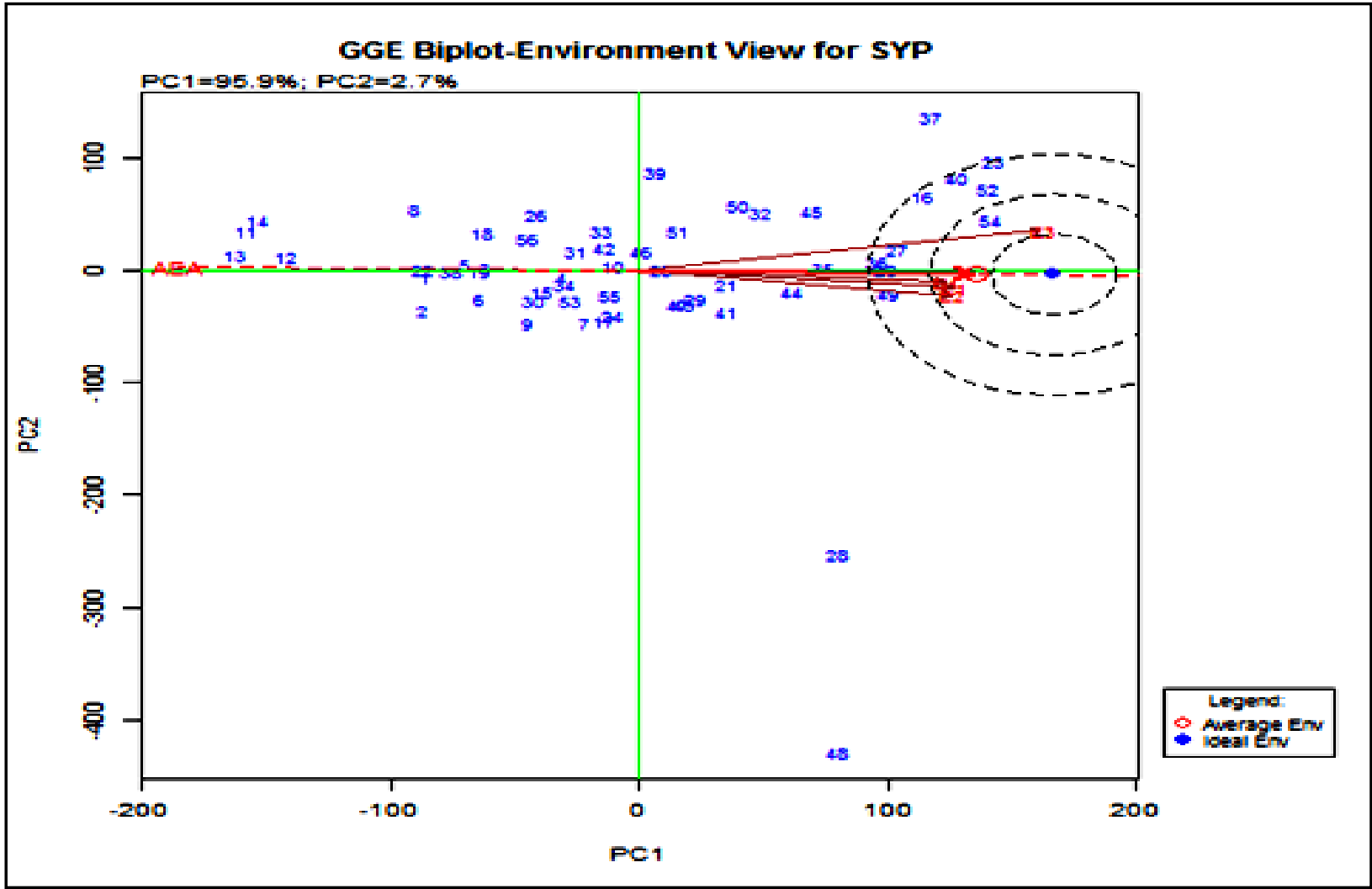

Figure 3 Comparison of all the environments with an ideal environment. The genotypes and environments are indicated by $\mathrm{E}$ and numeric value, respectively.

indicating poor stability. Therefore, it become apparent that in the current study, genotype $\mathrm{G}_{54}(119.79 \mathrm{~g})$ was highest average seed yielder with consistent stability followed by $\mathrm{G}_{23}(119.41 \mathrm{~g})$, $\mathrm{G}_{52}(119.20 \mathrm{~g})$ and $\mathrm{G}_{40}(116.07 \mathrm{~g})$ which were located very close to the genotype $\mathrm{G}_{54}$ (Figure2).Our result were similar to to the analyzed results of Eberhart \& Russell model (1966) of the present study and can be recommended for cultivation across different environments in Western India

\subsection{Evaluation of an en vironment based on GGE biplots}

Nevertheless, potential of genotype to deliver maximum performance is locked into the genome. Yet is a cumulative function of genotype to environment. Therefore, ascertaining unbiased and whole representative environment that is suitable for genotype under testing is a complex yet prerequisite job. For MET with the question of phenotypic stability study, screening of genotype over "ideal" and discriminating environment is major emphasize job.

In current study, "ideal environment" (Figure 3) is represented by a small circle with an arrow pointing to it and further other environment are ranked based on distance from ideal environment. The pattern of environment in the biplots (Figure 3) on the basis suggested that all the environments were clustered in one group. In the present study, as the angle between any two environments was less than $90^{\circ}, \mathrm{G} \times \mathrm{E}$ was moderately small and these environments tend to discriminate among genotypes in a similar manner. The environment, $\mathrm{E}_{3}$ found to be far away from the origin of the plot and had the shortest projection onto AEA Y-axis signifying most discriminating environment. Both $\mathrm{E}_{3}$ and $\mathrm{E}_{4}$ depicted the longer vectors indicating the best environments for genetic discrimination of the genotypes, while, the environments, $\mathrm{E}_{1}$ and $\mathrm{E}_{2}$ were observed to be least representative environments in current study. A strong relationship was present between $\mathrm{E}_{3}$ and $\mathrm{E}_{4}$ based on the minimum angles between the vectors of them. The environments $E_{4}$ and $E_{2}$ were positioned close to $E_{1}$, respectively. This showed that stable production of pigeonpea is possible in this environment. As per Tonk et al. (2011), these were the best environments for genotypes differentiation, while, the environment which showed large projection onto the AEA Y- axis suggesting them to be unfavorable and didn't have ability to discriminate the genotypes (Figure 3).

\section{Conclusion}

Understanding of decoding phenotypic stability of genotype is a major concern and it emphasize that $\mathrm{G} \times \mathrm{E}$ interaction benchmark 
tremendous potential for deciphering stability of genotype. The present study clearly partitioned the effect of $\mathrm{G} \times \mathrm{E}$ interaction for seed yield and other related component traits associated with building up total $\mathrm{G} \times \mathrm{E}$ interaction. The traits, plant height and pods per plant illustrated positive correlation with seed yield across the four environments. Seed yield also exhibited a significant and positive relationship with days to maturity in kharif 2013 at both the locations and pod clusters per plant in kharif 2013 and 2014 at Bhiloda. It indicated that these characters may be used in selection indices for amelioration of seed yield in pigeonpea. From the GGE biplot analysis, it was also concluded that in "ideal" view, the genotype $\mathrm{G}_{54} /$ GT $610 \mathrm{~A} \times$ GTR-84 (119.79 g) was the closest to the ideal genotype, followed by G52/ GT610 A $\times$ GT R-82 (119.20 g) and $\mathrm{G}_{40} / \mathrm{GT} 607 \mathrm{~A} \times$ GTR-82(116.07 g).

\section{Acknowledgement}

All the authors would like to thank the authorities of S. D. Agricultural University, Sardarkrushinagar, India, for providing facilities to complete the research work successfully.

\section{References}

Anonymous (2017) Pulses data book. Area, production and yield of different Pulses in India. Indian Institute of Pulses Research (IIPR). Kanpur, India. Available at http://www.iipr.res.in/e-pulsedata-book.html access on14/06/2017.

Borlaug NE (1972) Building a protein revolution of grain legumes. In : Nutritional improvement of food legumes by breeding. In : Proceedings of the protein Advisory Group, 3-5 July, 1972, FAO, Rome, Italy, Pp. 7-11.

Brick M, Fisher M (2016) International Year of Pulses. Crops and Soils 49: 38-38.

Chand U, Tikle AN, Kumar N, Saxena KB, Chaudhar S (2014) Yield stability in pigeonpea hybrids [Cajanus cajan (L.) Millsp.] under varying agro-climatic regions. Ratarst vo i povitarstvo 51: 717. doi: $10.5937 /$ ratpov $51-5326$

Eberhart SA, Russell WL (1966) Stability parameters for comparing varieties. Crop Science 6: 36-40. doi:10.2135/cropsci1966.0011183X000600010011x

Gabriel KR (1971) The biplot graphic display of matrices with application to principal component analysis. Biometrika 58 : 453467. DOI: $10.2307 / 2334381$

Graham PH, Vance CP (2003) Legumes: importance and constraints to greater use. Plant Physiology 131: 872-877. https://doi.org/10.1 104/pp.017004
Mula M, Saxena KB, Kumar RV, Rathore A (2010) Effect of spacing and irrigation on seed production of CMS-based pigeonpea hybrid. Green Farming 1: 221-227.

Pagi NK, Ravindrababu Y, Dharajiya DT, Patel JM, Patel MP (2016) Heterosis for seed yield and its component characters in pigeonpea [Cajanus Cajan L. Millsp.]. International Journal of Agriculture Science 8:3391-3395.

Patel MP (2004) Heterosis, combining ability and stability analysis in pigeonpea [Cajanus cajan (L.) Millsp.]. Ph.D. Thesis submitted to the Gujarat Agricultural University, Sardarkrushinagar, Gujarat, India.

Patel PT, Chauhan RM, Parmar LD, Tikka SBS (2009) Phenotypic stability of yield and related traits in pigeonpea. Legume Research 32: $235-239$.

Pawar RM, Tikka SBS, Sawant DM, Patil AD (2013) Stability analysis for biometrical traits in pigeonpea (Cajanus cajan L. Millsp.). BIOINFOLET-A Quarterly Journal of Life Sciences 10: 1307-1311.

PB Tools, version 1.4. (2014) Biometrics and Breeding Informatics, PBGB Division, International Rice Research Institute. Los Baños, Laguna.

Phad DS, MadrapI A, Dalvi VA (2005) Studies on Genotypes $\times$ Environmental interaction and stability in pigeonpea [Cajanus cajan (L.) Millsp.]. Indian Journal of Pulses Research 18: 156-157.

Reddy LJ, Green JM, Sharma D (1980) Genetics of Cajanus cajan (L.) Millsp. $\times$ Atylosia spp. pp. 39-50.In : Proceedings of the International Workshop on Pigeonpeas. Publisher ICRISAT, Patancheru, India.

Sa wargaonkar SL, Saxena KB, MadrapI A, Rathor A (2011) Stability analysis of yield and related traits in pigeonpea hybrids. Journal of Food Legumes 24: 184-193.

Saxena KB, Kumar RV (2003) Development of a cytoplasmic nuclear male-sterility system in pigeonpea using $C$. scarabaeoides (L.) Thouars. Indian Journal of Genetics 63: 225-229.

Saxena KB, Kumar RV, Srivastava N, Bao (2005) A cytoplasmicnuclear male-sterility system derived from a cross between Cajanus cajanifolius and Cajanus cajan. Euphytica 145: 289-294.

Singh NK, Gupta DK, Jayaswal PK, Mahato AK, Dutta S, Singh S, Pal JK (2012) The first draft of the pigeonpea genome sequence. Journal of Plant Biochemistry and Biotechnology 21: 98-112. 
Sreelakshmi C, Shivani D, Kumar S (2010) Studies on genotype $\times$ environment interaction and stability in white seeded pigeonpea genotypes. Legume Research 333:217-220.

Srivastava RK, Rathore A, Vales MI, Vijaya Kumar R,Panwar S, Thanki HP(2012) GGE biplot based assessment of yield stability, adaptability and mega-environment characterization for hybrid pigeonpea (Cajanus cajan). Indian Journal of Agricultural Sciences 82: 928-933.

Tikka SBS, Parmar LD, Chauhan RM (1997) First record of cytoplasmic-genic male-sterility system in pigeonpea [Cajanus cajan (L.) Millsp.] through wide hybridization. GAU Research Journal 22: 160-162.

Tonk FA, Ilke E, Tosun M (2011) Evaluation of genotype $\times$ environment interactions in maize hybrids using GGE biplot analysis. Crop Breeding and Applied Biotechnology 11:1-9.

Van der Maesen LJG, Nene YL, Hall SD, SheilaVK (1990) The Pigeonpea. In Pigeonpea: origin, history, evolution and taxonomy: pp. 15-46.

Vanniarajan CP, Rangaswamy J, Nepolean T (2007) Stable and unstable pigeonpea genotypes for yield vs. component characters. Plant Archives 7: 427-428.

Vanniarajan CP, Rangaswamy J, Ramalingam J, Nadarajan N (2000) Genetic analysis of yield and important yield traits in hybrid pigeonpea. Crop Research Hisar 8: 266-272.
Varshney RK, Chen W, Li Y, Bharti AK, Saxena RK, Schlueter JA, Farmer AD (2012) Draft genome sequence of pigeonpea (Cajanus cajan), an orphan legume crop of resource-poor farmers. Nature Biotechnology 30: 83-89.

Wanjari KB, Patil AN, Fulzele GR, Ghavghave PB (1988) A note on stability analysis in pigeonpea (Cajanus cajan (L.) Millsp.). Annals of Plant Physiology 2: 113-114.

Williams EJ (1952) The interpretation of interactions in factorial experiments. Biometrika 39: 65-81

Yan W (1999) A study on the methodology of cultivar evaluation based on yield trial data - kwith special reference to winter wheat in Ontario, Ph.D. Thesis submitted to the University of Guelph, Guleph, Ontario, Canada.

Yan W, Kang MS (2003) GGE biplot analysis: a graphical tool for breeders, geneticists and agronomists. $1^{\text {st }}$ ed. CRC Press, Boca Raton, FL, USA.

Yan W, Kang MS, Ma B, Woods S \& Cornelius PL (2007) GGE biplot vs. AMMI analysis of genotype-by-environment data. Crop science 47 : 643-653.

Yan W, Hunt LA, Sheng Q, Szlavnics Z (2000) Cultivar evaluation and mega-environment investigation based on the GGE biplot. Crop Science 40: 597-605.

Yan W \& Tinker NA (2006) Biplot analy sis of multi-environment trial data: Principles and applications. Canadian Journal of Plant Science 86 : 623-645. 